\title{
Clocks and Crime: Conceptions of Time in the Writings of Cesare Lombroso
}

\section{Paul Knepper}

\section{(2) OpenEdition \\ 12 Journals}

\section{Electronic version}

URL: http://journals.openedition.org/chs/2265

DOI: $10.4000 /$ chs.2265

ISSN: 1663-4837

\section{Publisher}

Librairie Droz

\section{Printed version}

Date of publication: 31 December 2018

Number of pages: 9-29

ISSN: 1422-0857

\section{Electronic reference}

Paul Knepper, "Clocks and Crime: Conceptions of Time in the Writings of Cesare Lombroso", Crime, Histoire \& Sociétés / Crime, History \& Societies [Online], vol. 22, n² | 2018, Online since 31 December 2020, connection on 13 April 2021. URL: http://journals.openedition.org/chs/2265 ; DOI: https:// doi.org/10.4000/chs.2265

\section{This text was automatically generated on 13 April 2021}

(c) Droz 


\title{
Clocks and Crime: Conceptions of Time in the Writings of Cesare Lombroso
}

\author{
Paul Knepper
}

\section{Introduction}

Cesare Lombroso occupies a curious position in the history of criminology. In the late nineteenth century, he popularized the scientific study of criminal behaviour with a flawed aetiological theory, mistaken research methodology and misguided prevention schemes. ${ }^{1}$ His work, or rather, the critical response to his work, led to the development of criminology as a social science. As Rock observes, generations of criminologists have announced their projects by distancing themselves from Lombroso. ${ }^{2}$ Even biosocial criminologists, who advocate a body-centred approach to social science, make a point of declaring their opposition to Lombroso. ${ }^{3}$

2 The starting point for rejecting Lombroso is the "born criminal", a phrase often used as a summary of his theory of atavistic criminality. Lombroso proposed the origins of criminal behaviour are found in the remote past and pointed to vestiges of the evolutionary process within the criminal body. ${ }^{4}$ A point that has been made, yet not fully appreciated, is that Lombroso continued to expand and modify his views. There were five editions of L'uomo delinquente, "Criminal Man", between 1876 and 1897, and the final version swelled to four volumes. ${ }^{5}$ Not only did he incorporate a number of factors associated with crime in addition to atavism, he revised the concept of atavism itself. Specifically, he departed from the concept of deep time on which it was based.

This article will critique six conceptions of time in Lombroso's books and articles. To an extent, he pursued alternative conceptions of time to repair problems that became apparent in his theory of deep time. But Lombroso never attempted to formulate a coherent, comprehensive theory; rather, he added new material to old, never bothering to address contradictions and inconsistencies. ${ }^{6}$ Yet, as he turned to other topics, he 
found less use for atavism as an explanation. Lombroso himself moved some distance from what Garland refers to as "the Lombrosian project", the effort to distinguish scientifically criminals from non-criminals. ${ }^{7}$ In developing alternative conceptions of time, he explains the criminal behaviour of "normal" or "ordinary" people without physiological or psychological deficiencies.

4 Near the end of his life, Lombroso announced that he no longer believed in the superiority of European civilization. In his final book, he declared that "primitive peoples" were nearer to truth than scientists in advanced societies. ${ }^{8}$ What will emerge from the following discussion is an argument for the importance of history in understanding crime. If Lombroso began his intellectual career as a scientist, he ended it as an historian. The advance of scientific thinking led to a loss of knowledge and the purpose of criminology is to recover it.

\section{Traces of deep time}

5 At the center of Lombroso's intellectual project was his Museum of Psychiatry and Criminal Anthropology. ${ }^{9}$ It began with a collection of skulls he acquired while working as a medical doctor in prisons and asylums. Lombroso revealed his collection to the public for the first time in 1884 as part of the anthropology exhibition at Turin's Espoizione Generale Italiana. When the International Congress of Criminal Anthropology met in Rome a year later, he brought an extensive display. ${ }^{10}$ Lombroso filled the main hall of the Palazzo delle Belle Arti with skulls arranged on tables, body parts floating in alcohol-filled jars, and faces revealed in photographs and death masks. The exhibition contained some 70 skulls of criminals, the entire skeleton of a thief, and sections of skin with tattoos. He displayed aspects of the criminal's body in 300 photographs, life-size sketches and handwriting samples. ${ }^{11}$

6 In 1892, Lombroso learned that the director-general of prisons, Count Bertrani-Scalia, had a collection of skeletons stored at Regina Coeli and was thinking of starting a museum. It was just the thing Lombroso had in mind. ${ }^{12}$ Lombroso opened the Museum of Psychiatry and Criminal Anthropology at the University of Turin in 1899. It included a corridor of skeletons, allegedly those of notorious brigands from Southern Italy. The largest room contained a scale model of Eastern State Penitentiary in Philadelphia, surrounded by portraits on the walls of criminals and epileptics. Lombroso displayed "criminal types" obtained from government authorities in Spain, Mexico, Portugal, Chile and Australia. He filled glass display cases with daggers used by Camorra; crucifixes of prisoners seeking redemption; and pottery pieces containing inscriptions of robbers and murderers. He displayed items made by prisoners, including a court scene molded from clay and sketches of shootouts with Carabinieri. ${ }^{13}$

7 The museum seems nothing more than a jumble of trivial, odd and sinister items, but to Lombroso, it represented a method of scientific inquiry into deep time..$^{14}$ In the early nineteenth century, "deep" or "geological" time inspired work across various fields of inquiry. ${ }^{15}$ It was a period of history before science became a specialized vocation and the laboratory the standard institution, when amateurs contributed to scientific discussions and the museum was the preeminent site for research. Darwin is often mentioned as an inspiration for atavism. Lombroso may have borrowed the idea from a comment about "black sheep" in The Origin of Species (1859). Mazzarello notes that Lombroso could have acquired a French translation in Pavia as early as $1862 .{ }^{16}$ But, as 
Pancaldi points out, the concepts of evolutionary development in Lombroso's work, as well as the citations in his texts, point to the influence of pre-Darwinian evolutionary theory. ${ }^{17}$

8 The idea that the earth was not thousands, but millions of years old, raised profound questions, particularly about the origins and development of human beings. Robert Chambers caused a stir in the 1840s with his book Vestiges of the Natural History of Creation, in which he made creation the subject of natural history. He brought together material from astronomy, geology, chemistry, physics, phrenology and anthropology to show how isolated findings illustrated a grand narrative of development. Events that had taken place in the deep history of the earth could be observed through remnants or traces that had survived in the present. In a chapter on the "mental constitution of animals", Chambers previewed the concept that would make Lombroso famous: "Does God, it may be asked, make criminals? Does he fashion certain individuals with a predestination to evil? He does not do so; and yet the criminal type of brain, as it is called, comes into existence in accordance with laws which the Deity has established". ${ }^{18}$

Lombroso brought deep time to criminal behaviour. The objects in his museum represented traces of deep time; remnants of the prehistoric past that had survived into the present. He used the term atavism to mean that some people were frozen in an earlier stage of evolutionary development. The criminal was "an atavistic being who reproduces in his person the ferocious instincts of primitive humanity and inferior animals". ${ }^{19}$ The skull explained other peculiarities: enormous jaws, high cheek-bones, prominent arches, prominent ears, all found in savages and apes; as well as insensitivity to pain, acute sight, tattooing and insatiable aggression. Lombroso also used the term degeneration, which included the idea that criminals could move further back on the evolutionary scale. ${ }^{20} \mathrm{He}$ accepted the Lamarckist position that acquired traits could be inherited and become permanent. Many social reformers who turned to the new science of evolution to support their proposals found Lamarck's version more suitable for their purpose than Darwin's. ${ }^{21}$ Research in the 1890s, Lombroso concluded, confirmed the theory that the social environment has a permanent effect on physiology. He offered evidence of this in the camel's hump and psychological traits of European peoples, specifically, Jews. The fierce persecution of Jews over the centuries meant that "bold resistance" was of no use; instead, Jews acquired the appearance of "meanness and sordidness" as a defence. ${ }^{22}$

10 Lombroso has been seen as an incompetent researcher who failed to follow the experimental method. ${ }^{23}$ His method of inquiry does not make sense apart from deep time. He actually does follow what is now the ordinary working equipment of a range of the historical sciences, including geology, cosmology, archaeology and astronomy. Because the problems they study result from causes in the remote past, investigators in the historical sciences cannot create experimental conditions in the laboratory. Rather, they try to reconstruct past events from physical traces that have survived into the present. Cleland outlines the method: first, assemble a collection of traces; second, propose a common cause; and, third, provide a unifying explanation. ${ }^{24}$ She refers to the third step as a search for "a smoking gun", the discovery of a trace that clinches the case for a particular causal story. ${ }^{25}$

11 Lombroso found traces in the shape of ears, distance between toes, thickness of hair and other characteristics of the body. He had common cause in atavism and degeneration, and 1870, he found his smoking gun. While at Pavia conducting an 
autopsy of a notorious brigand, Guiseppe Villela, Lombroso allegedly noticed that the shape of the cranium resembled that of inferior animals. He had "not merely an idea, but a revelation". He had solved the problem of the nature of the criminal: a species of humanity arrested at an earlier stage of evolutionary development. ${ }^{26}$ But, as Cleland points out, the process can go awry. According to the logic of historical science, there should be multiple traces of natural causes from the past, but "the trick is finding them". ${ }^{27}$ There needs to be something puzzling about the traces to suggest a common cause or source; simple correlations can result from separate causes. ${ }^{28}$

The speed at which Lombroso worked, the ambiguity of his concepts, and his casual approach to statistics meant that he accepted even superficial connections as justification for presuming a common cause. He quickly absorbed various materials into his narrative, which left mistakes, contradictions and nonsense. Other criminologists studied tattoos, too, but did not always reach analogous conclusions. ${ }^{29}$ Alexandre Lacassagne, for example, took an interest in tattoos while working in Algeria as a military surgeon attached to a disciplinary brigade, and he also noticed many soldiers had tattoos with exotic designs and curious inscriptions. He developed a technique for transferring the designs to paper, and looked for correlations between elements of design and location on the body. In his first paper on the subject, he adhered to Lombroso's theory, and proposed a correlation between the number of tattoos and the frequency of criminal activity. But Lacassagne abandoned the idea of tattoos as a trace of atavistic criminality, and shifted instead to a seeing the tattoos as an element of the criminal underworld or subculture. ${ }^{30}$

13 There is no such thing as "definitive proof" of a smoking gun. ${ }^{31}$ It is always possible that further discoveries will supplant the prevailing theory with another approach. Further, many of the factors that contribute to finding a smoking gun are "sociological or psychological, as well as theoretical and empirical" ${ }^{32}$ In other words, there is room for prejudice, politics and other subjective factors in the designation of a leading explanation. Lombroso began his search for the natural origins of crime within a racist view of human development and this led to many false assertions.

For Lombroso, degrees on the evolutionary scale of human development corresponded with racial divisions. In L'uomo bianco e l'uomo di colore (1871), "The White Man and the Man of Colour", he explained that originally all people had dark skin. As evolution took place, lighter skin emerged, eventually leading to the emergence of the "white man". At the present state, the "coloured man" remained closer to the primate than other races. This "science" confirmed the political affairs in which European powers operated colonial empires; as the most highly evolved, the European races displayed the most highly advanced civilizations. He revealed a contemptible dismissal of non-white races, and viewed native peoples of the Americas, Asia and especially Africa as inferior beings. Lombroso's racist outlook applied to Europe as well, specifically, to the southern tip of the Italian peninsula. He judged the inhabitants of Calabria and Sicily to be racially inferior owing to the mixture of African and Arab blood. ${ }^{33}$ So, Villela's skull provided the smoking gun only because of the racist psychological and sociological lens through which Lombroso viewed it. ${ }^{34}$ 


\section{Time moves at multiple speeds} homicide in the United States. He offered a wide-ranging explanation for why the United States, which had claimed the vanguard of civilization (and leapt a hundred years ahead of Europe), also had an increase in homicide rates, year after year. Given his racist outlook, it is no surprise that he suggested that if Black violence were removed from the statistics, American levels of homicide would compare favourably with European levels. He went on to argue that within the White race, the paradox was explained by the juxtaposition of civilization and barbarism. He observed that rates fluctuated across geographic areas, a difference that could be attributed to immigration, but also a reaction to bad government. Where the authorities proved unable to contain violence and police proved inept at preserving safety, the population resorted to their own forms of control, similar to the residents of Sicily and Calabria. ${ }^{41}$

19 In discussing the remedies, Lombroso referenced the impact of polite society and conscience formation. Compared to Europe, the pace of political reform moved more quickly. Americans were far more willing to experiment with prison treatments and novel methods of reforming offenders. Lombroso praised Zebulon Brockway's reformatory scheme at Elmira, New York. ${ }^{42}$ He also referred to another influence of polite society. Temperance societies had replaced taverns and dance halls with coffeehouses and places of popular entertainment. Shifting the site and type of leisure activity, from bar-rooms frequented by the criminal element, to those of civilized 
society, would remove a source of crime and bring about a reduction of homicide visible in statistics. ${ }^{43}$

Lombroso had a sense of the de-civilizing process as well. The course of natural history proceeded by opposing forces of progression and regression; regression led to progression. Every organ that atrophied and was lost gave way to a new organ better fitted to the environment. Lobsters lost gills but gained appendages with claws; birds lost gills but gained wings. Human beings lost a tail and fur, but gained a thumb and a bigger brain. "What has been said of the animal species... is illustrated in this history of nations", Lombroso said, "for we see peoples extraordinarily advanced in one direction presenting marked characteristics of retrogression". ${ }^{44}$ England developed the most liberal monarchy of Europe, and quietly implemented socialist policies, yet preserved aristocratic lords and judges reminiscent of the Normans. The English professed to be an advanced and practical people, but looked back to the Bible for a requirement that made Sunday idleness a national duty. ${ }^{45}$

There is, nevertheless, a significant difference between Elias's view of the civilizing process and Lombroso's. Elias took his understanding from Freud, and consequently, understood "conscience formation" as a mental process. The formation of polite society occurred within the imagination, and imagination furnished the foundation of European culture. For Elias, this was a slow, gradual process that occurred at different speeds in particular places. He did not intend for his theory to be read as an evolutionary transition from violence to peace as Pinker proposes. ${ }^{46}$ For Lombroso, the civilizing process operated within the body. He equated European culture with evolutionary progression; European peoples had reached a more advanced stage of physiological development. The pace of civilization adhered to a biological clock, and this offered a reasonable explanation so long as it remained at a high level of abstraction. Evolutionary development of the body, including the brain, could serve as the ultimate cause of human behaviour. ${ }^{47}$

At the time of fifth edition of L'uomo delinquente, published in 1897, Lombroso retained his disdain for "primitive societies". But he had also become sceptical about the achievements of modern civilization. Modern life gave people new appetites and new techniques for committing crime. ${ }^{48}$ This collided with his belief in role of scientific thought in advancing progress, another conception of time in his work.

\section{Time is progress}

Lombroso was born in Verona, Italy, in 1835 to a Jewish family. Like other Jews, he supported formation of the Italian state because it meant escape from centuries-old restrictions imposed by Catholic authorities. Until a few decades before Lombroso was born, the Jews of Verona had been confined to a ghetto. After 1870, when unification was complete, Lombroso pursued assimilation into Italian life as did many other Jews. He shared with Jews of his generation the vision of an acculturated and secular future. He declared himself to be a scientist dedicated to turning back the religious obscurantism of religion, not only Catholicism but Judaism as well. ${ }^{49}$ Lombroso described the triumph of modern, scientific understanding over superstitions, religious beliefs and legal concepts. His "discovery" of atavistic forces at work in human development registered as one of the great scientific achievements in the age of science 
and technology. Now that he had made his breakthrough, there could be no turning back. The progress of science was inevitable, he believed, and could not be reversed. ${ }^{50}$ it as "criminal anthropology" and the "positive school" to emphasize the science of the criminal body as opposed to an abstract legal conception of morality. By 1884, La scuola Lombrosiana spread from Italy to Germany, Russia, France, Belgium, Hungary and England. Scientists in these countries, as he put it, "filled the lacunae of my original conception and have developed legal applications for my ideas". ${ }^{51} \mathrm{He}$ continually referred to work by others - even those who made a point of expressing their disagreement with him - as contributing to the progress of the school of thought he had founded..$^{52}$ At the congresses of criminal anthropology at Rome in 1885 and Paris in 1889, Alexandre Lacassagne and Paul Brouardel dismissed Lombroso's "discovery". There was no criminal type of human being. They insisted that social milieu had more to do with criminal behaviour than inheritance. ${ }^{53}$ Lombroso actually did not deny the relevance of social milieu and neither did he recognize it as a critique of his approach. He simply absorbed it into his own thinking. At the Geneva congress of criminal anthropology in 1896, Lombroso's allies put forward a formal resolution to declare that crime was a phenomenon with biological and social origins. This was, as Enrico Ferri put it, the "final conclusion" of Lombroso's school; the importance of the social environment in producing crime had been part of it from the beginning. ${ }^{54}$

Lombroso believed his school would bring about a revolution in the prevention of crime and the treatment of offenders. Lombroso referred to this as "social defence". Crime was part of the natural order, a necessary part of society, but so is defence against it, and thus punishment. Punishment need not be justified by archaic concepts of sinful nature or human will, but scientific principles. When based on social defence, punishment becomes more logical and effective..$^{55}$ Owing to the advent of social defence, crime would decrease throughout the twentieth century. In London and Geneva, where preventive measures had been put into place such as lifelong confinement of incorrigibles and seclusion of insane criminals in asylums, crime rates declined year after year. "In the coming century", Lombroso wrote in a paper unpublished during his lifetime, "obstacles in the way of reforms will be removed by the adoption of many of the most essential measures suggested by our school" ${ }^{56}$ The twentieth century would bring large-scale agricultural colonies for abandoned children, unemployed and vagrants. Through such reforms, Lombroso's positive school would eliminate delinquency. In the few prisons that remain, there would be libraries, schools, and useful employment. ${ }^{57}$

In describing social defence, Lombroso lapsed into the Whig view of history: time inevitably entailed or equalled progress. In viewing evolution as the chief reason for progress, Lombroso joined lawyer-historians Luke O. Pike (1876) and Oliver Wendell Holmes Jr. (1881). No longer did time present a combination of opposing forces, flow and contra-flow. Now it appeared as a staircase ascending from the darkness of superstition and ignorance into the light of insight and understanding. Old legal practices, and the ideas on which they are based, would give way to new practices enabled by news ideas. The result would be greater humanitarian and democratic outcomes; better prisons, better treatment, and a better society. Lombroso did not foresee how social defence would come to justify fascist policies in Hitler's Germany, Stalin's Russia and Mussolini's Italy.

Crime, Histoire \& Sociétés / Crime, History \& Societies, vol. 22, n² | 2018 

To explain patterns of crime among Jews, he relied less on racial terms than sociological language. Some kinds of crime committed by Jews, such as financial crimes, reflected the persecution and discrimination that had excluded Jews from other pursuits. He invoked atavism instead to characterize the "anti-Semitic wind" gusting across Europe. "Anti-semitism is an atavistic phenomenon", Lombroso wrote in 1897, "which has its basis in the lowest passions of mankind". ${ }^{58}$ He wrote a short book, L'antisemitismo e le Scienze Moderne (1894) and several articles in which he consistently defended Jews from racist attacks. ${ }^{59}$ Nevertheless, La scuola Lombrosiana framed the structure of criminal biology as implemented in National Socialist Germany and supported Nazi assertions of criminals as biologically inferior and psychologically abnormal individuals.$^{60}$ Criminal anthropology contributed to Mussolini's racial laws of 1938. A number of Lombroso's friends and colleagues joined the Fascist party. Salvatore Ottolenghi, a former student, became a "Jewish fascist". He praised Mussolini for grasping Lombroso's teaching that "one cannot understand crime if one does not study the criminal". ${ }^{61}$

Lombroso's racialized conception of the criminal type contributed to the tradition of scientific racism, and in arguing for government control over supposedly inferior populations, fortified rationales for colonialism and imperialism. Lombroso also advocated the death penalty for repeat violent offenders and members of criminal gangs. Italy abolished capital punishment in the Zanardelli code of 1889 , and critics challenged his preferred policy. Lombroso insisted that the death sentence was consistent with the laws of nature: "progress in the animal world, and therefore in the human world, is based on a struggle for existence that involves hideous massacres". In the fifth edition of L'uomo delinquente, Lombroso noted that society need spare no sentiment for atavistic criminals, who are "programmed to do harm" and reproduce in their being "not only savage men but also the most ferocious carnivores and rodents". ${ }^{62}$

\section{Time moves in fits and starts}

Lombroso encountered resistance to his ideas. In 1889, at the second congress of criminal anthropology in Paris, Leonce Manouvrier dismissed atavism as nothing more than a variation of the "demolished science of phrenology". ${ }^{63}$ At the fourth congress at Geneva, the Russian delegate Zakrewsky was inclined to "laugh at the whole thing" and ridiculed Lombroso openly. ${ }^{64}$ Gino C. Speranza, advisor to the American Institute of Criminal Law and Criminology, characterized Lombroso's work as "a mixture of facts and nonsense" and "scientific fiction". ${ }^{55}$ In Britain, Charles Whibley, editor of Blackwood's Magazine, denounced criminal anthropology as a "false science" and "absurd thesis". ${ }^{66}$ Lombroso was prepared to meet such criticism with another conception of time. History advances toward the future, not in steady, gradual development, but revolutionary moments. Inertia represents a brake on progress, then a scientific discovery occurs, and time leaps forward into the future.

In the 1880s, Lombroso began a study with Rodolfo Laschi, a lawyer in Verona, of anarchist criminals. From the 1860s, anarchists or "internationalists", became visible in southern Italy where Russian revolutionary Michael Bakunin attracted a number of followers. In the 1870s, demonstrations took place in Tuscany, Romagna and Naples, and anarchists attempted to convert these to anarchist movements. At Florence and

Crime, Histoire \& Sociétés / Crime, History \& Societies, vol. 22, n² | 2018 
Pisa, anarchists tossed dynamite into crowded streets, and in 1878, Passanante attempted to murder King Umberto I. Lombroso and Laschi produced their work on anarchist criminality during a period of rule in Italy of Francesco Crispi who served as prime minister during 1887-1891 and 1894-1896. Crispi achieved his popularity through an aggressive foreign policy which aspired to expand his control into the Mediterranean. He envisioned Italy as a great imperialist nation and began a program of rearmament. He sought at alliance with Germany, which Lombroso's associate, Helen Zimmern, was keen to prevent. In 1894, Crispi introduced anarchist/socialist laws modelled on those Bismarck had introduced in Germany. ${ }^{67}$

31 In their two-volume study, Delitto politico e la rivoluzione, "Political Crime and Revolution", Lombroso and Laschi theorized that in society, as in nature, the law of inertia prevails. ${ }^{68}$ In society, this was misoneism, or hatred of novelty; political, religious and social institutions resist change. For change to occur, the institutional order must be challenged, and these challenges can be characterized as rebellions or revolutions. Rebellions register retrogressive change. Sparked by a passionate or neurotic individual, they are marked by drunkenness and criminality. Revolutions register progressive change; they are planned, prepared, and characterized by true genius among their leaders. Anarchist criminals contribute to rebellions through their misguided attempts at rapid social change. They are artificial because they do not harmonise with nature. Changes that were too abrupt did not originate in the physiological condition of human nature, and because they took place outside the natural order were less likely to establish permanent change. Lombroso advised reformers to work within the scope of tradition. "Progress, to be accepted, must be slow, otherwise it is futile and mischievous". ${ }^{69}$

Lombroso's theory of political crime left him with two dilemmas, however. First, how was it possible to distinguish revolution from rebellion? The law of misoneism meant that all challenges, whether the barbaric rant of a madman or the vision of a genius ahead of their own time, would be resisted. Revolutionaries and rebels would be met by opposition; both would be seen as anti-social, and therefore, criminals. He decided that revolutions could be distinguished from rebellions only in retrospect. Given the hindsight of history, it was possible to separate anarchists from ordinary criminals. For this reason, he reversed his position on the death penalty. Executions could stifle the future by eliminating the source of progressive change. Lombroso advocated penal colonies for anarchists. "I am an extremist in my partisanship for the death penalty... but we have to do a very different thing here".$^{70}$ Lombroso said that within the ranks of political criminals, there was greater evil than that found within the ordinary population, but that it was capable of taking an altruistic turn. If properly directed, the energy that produced death and destruction could be channelled into service to humanity. ${ }^{71}$

Lombroso had to say this because of his own position. He placed himself in the same category as all the great scientists who ignited a revolution in thought. If he had made his attack on the church and government authorities at an earlier point in history, he might have been imprisoned, or, put to death. "Lombroso is an interesting case in point", Helen Zimmern observed, "From early youth he possessed the art of divining fruitful ideas, which at the time seemed absurd to scientific men as well as the public. Every line of investigation he took up was at the time apparently opposed to the current tendency of thought and only received attention at a later date". ${ }^{22}$ 

criminality. Railway links between ports and cities, and the concentration of commerce in cities, encouraged criminals to congregate in urban areas where they could expect higher profits and greater anonymity. ${ }^{74}$ It was necessary to develop innovative defences against the new weapons afforded criminals by urbanization and modern life. In England, where politicians talked about preserving personal liberties, a recent authority had advocated the suppression of criminal safe houses. The Americans had invented a more practical solution: security companies. An American firm had devised an alarm that could signal the presence of an intruder from a switch fixed near the bedstead. The turn of a key activated a telegraph link to the telegraph office, which notified the police. Trains and telegraphs represented advances in the fight against crime as well as tools to commit crime. They offered a means of neutralizing the new weapons of crime empowered by the advance of technology in society. ${ }^{75}$ Every new technology adapted into ordinary life afforded new possibilities for criminality, from the railroad to the phonograph, Lombroso said, but none more so 
than the bicycle. Although cycles had been around since the late eighteenth century, cycling did not become popular until the late nineteenth century. In the early 1890 s, the safety bicycle appeared, with a chain-driven rear wheel equal in size to the front wheel and pneumatic rubber tyres. Relatively affordable for the expanding middle class, it afforded independent transportation for men and women. The "bicycle craze" began in France and spread across Europe, as well as Britain and the United States. Cycling enthusiasts formed social clubs, organized group tours, wrote newspaper columns and published magazines as more and more manufacturers promoted their models. Enthusiasts outdid themselves in setting records for time and distance; conversations turned to spokes, sprockets, bloomers and knickerbockers. Bicycling seemed to figure into everyone's plans, not only weekend outings and tours overseas, but also doctors making rounds, police on patrol, and politicians' campaigns. Women on bicycles became the theme of newspaper editorials, popular songs and detective fiction. The craze ended in 1896, but not before two university students completed an "around the world tour": 15,000 miles across Europe, Asia and America on two wheels. ${ }^{76}$

So important was the bicycle to criminal activity, Lombroso mused, it was necessary to replace the old adage cherchez la femme - a woman was the source of any conflict between men - with the phrase cherchez la bicyclette. The bicycle was a cause of crime, as young men would stoop to any level of immorality to get their hands on one. Theft often led to violence among otherwise reasonable men. It was also an instrument of crime; the bicycle provided a new means of highway robbery. The bicycle also brought about "minor or pseudo crimes". The Italian government, for example, had decided to levy a bicycle tax. Each machine would need to bear a stamp indicating it had been registered and the tax paid, and this led to petty crimes related to forged registration cards, fraudulent dealings with bicyclists visiting from foreign countries, and trading registration cards from one machine to another. At the same time, the bicycle brought changes in society likely to bring about a reduction in crime. Bicycling offered an alternative to alcohol, and public houses, especially in rural areas, adapted to the changing business environment. Many sold mineral waters, syrups and coffee. Bicycling contributed to physical fitness, reduced stress and forms of emotional depression. ${ }^{77}$

Lombroso realized therefore that natural time had been transcended. He would have been well aware of the adoption of global time or Greenwich Mean Time (GMT) in the 1880s. The present world system of reckoning time, with 24 hourly zones and a prime meridian at Greenwich, originated from an international conference held at Washington, DC, in 1884. In agreeing to Greenwich as the common zero of longitude and therefore, a single standard of time throughout the globe, the conference gained international recognition for an agreement reached at the 7th International Geodetic Conference, convened at Rome in $1883 .{ }^{78}$ Local time or time reckoned by nature - sun, stars, seasons, climate, and geography - had been replaced by universal time agreed by political institutions. The time in which natural processes unfolded became less important than the speed of transportation, communication, and commerce. ${ }^{79}$

\section{Time moves backwards}

41 Nearly the end of his life, Lombroso imagined yet another sense of time. A space in which there is no time that can be measured or is worth measuring. It appears in his 
work on spiritualism. Lombroso declared that the final focus and stage of the evolution of the Italian school of criminology was to understand the biology of spirits. His ambition was not merely to demonstrate the existence of the spiritual world, but to show that crime had its roots in evil spirits and demonic forces. Despite the interest in Lombroso's work, his studies of mediums, psychic phenomena and the spirit world have been almost completely neglected. ${ }^{80}$

Certainly, the spirit photographs played a part. In 1862, the American spiritualist movement received a boost when a Boston engraver claimed to have captured a ghost on film for the first time. He opened a studio in Boston and offered paying customers the opportunity to be photographed in the company of a deceased relative or friend. This led seven years later to a trial for fraud in New York, and the trial brought wide attention to spirit photography beyond the spiritualist movement. Spirit photographs appeared and reappeared in Europe during the 1870s and 1880s. Although repeatedly revealed as a mere photographic trick, spirit photographs remained a relevant practice within the spiritualist field into the middle decades of the twentieth century. ${ }^{81}$

Initially, Lombroso dismissed spiritualism. But after accepting an invitation to meet the spiritualist Eusapa Palatino in Naples, he observed a séance and became curious about the trances of mediums. He began his studies of spiritualism in the late 1880 s with visits to several "haunted houses" and, given his reputation as a secular intellectual pursuing a scientific explanation, his reports attracted wide attention..$^{82}$ As Lombroso recounted, the Pavarino family in Turin heard the sound of a water basin being overturned, yet no one else was in the room. The following morning, the bell attached to the entrance began to ring on its own. Members of the family heard continual groans. The youngest daughter awoke to the feeling of blows, but saw no one; in the morning, the sunlight revealed bruises on her body. The most curious aspect of Lombroso's work on haunted houses is not his thoughts about poltergeists, but about the people who make these statements. They were, Lombroso said, "a family of working people" and - the curious part is that - he believed them. Lombroso said that he had the occasion to report facts about hauntings, now so frequently reported and well-attested. Centuries had passed without anyone taking notice of them, except among the lower classes, who are not in communication with the educated classes. As he put it, "it is not that they did not occur; but that the educated classes no longer believed in them". ${ }^{83}$

Lombroso managed to write a book, shortly before his death, on his studies of spiritualism. After Death-What? (1909) repeats his account of haunted houses and includes material on hypnosis. ${ }^{84}$ It contains a distinct vision of time. Lombroso reports accounts from séance work by Leonara Piper. Piper's conduit to the spirit world revealed that space and time have no meaning. After death, spirits lose all conception of space and time, or make mistakes about them. Distances do not exist. Spirits seem to travel great distances, appearing minutes later, at a second location hundreds of miles from the first. Time, as well, seems irrelevant. On being asked by a medium to go and see what a person was doing at a certain time, the spirit returned to report what the person was doing the day after or thought the day before. ${ }^{85}$

But again, the most interesting part of Lombroso's work on spiritualism is not the idea of timeless after death, but the method by which he arrived at his conclusion that spiritualism was worth studying. "Perhaps the proof that appeals to me with most insistent force is the universality of the belief among all peoples (at least in humble classes who are nearer to the foundation of truth than they seem) in the existence not 
only of mediums and magicians... but of spirits, and especially the souls of the dead". ${ }^{86}$ He devoted an extensive chapter to the spiritual beliefs of people across Africa, India, and the American Indians. Although he referred to them as "primitive peoples" he insisted that they possessed deeper and more important knowledge than the advanced peoples of Europe. In making such an observation, he thus retreated from the racist hierarchy he established in his early work.

Perhaps Lombroso's remarks about the superior wisdom possessed by so-called primitive peoples, like his interest in the spirit realm and life after death, amounts to nothing more than the desperate statements of a dying man. His colleague, Hans Kurella, believed as much. Kurella (1911) said that Lombroso's misadventure into spiritualism undermined his reputation for pursuing scientific facts. Lombroso had anticipated that this would happen and defended his inquiry in advance. In the preface to After Death - What?, he compared scientific knowledge to mapping the islands across a wide sea; science could grasp what could be observed, but there was much more to be known. He had been wrong about science; scientific facts were not as permanent nor as objective as they appeared. He also suggested that he had been wrong about people; specifically, the people who came to him with ghost stories. He had dismissed their accounts as superstition or mental illness; now he thought there was more to them than this. ${ }^{87}$

In these later reflections, Lombroso reversed the arrow of time. Knowledge flows from the past and primitive existence to the future and advanced civilization. To understand their future, that is, life after death, civilized peoples must look back to the past: to ancient knowledge left behind by the rush of science and technology. The object of study is now the subject; the body no longer matters, but the mind. Memory of the past, not scientific observation of the present, will guide civilization. Lawrence (2012) points out that criminologists are not so much interested in understanding the present as in producing knowledge that will guide policy in the future. The putative superiority of scientific knowledge ought not provide justification for ignoring knowledge of the past. It is a lesson Lombroso seems to have learned in the course of his career.

\section{Conclusions}

Cesare Lombroso became famous for his theory that criminal behaviour originates in deep time. The causes of crime were to be found in pre-history and could be studied through traces left in the human body. But there are multiple conceptions of time in Lombroso's writing. Not only does he pursue deep time, but time moving at multiple speeds, time as progress, time moving in fits and starts, time speeding up, and time moving backwards.

Lombroso never attempted to reconcile these different conceptions of time into a unitary whole, although he seems to have realized that for deep time to succeed as an explanation for criminality, it had to be fortified with additional concepts of time. During the 1890s, after Lombroso revised L'uomo delinquente for the last time, he seems to be thinking less about pre-history than history. Articles on anarchism, homicide in the United States, and the bicycle and crime emerge in this period. To explain these different issues, Lombroso relied on history. He retained a sense of natural history at work in the production of anarchist criminals and his racist view of Black Americans, but he developed much more of his argument from conventional history. In thinking 
about the bicycle and crime, he makes no mention of primitive ancestry or psychical peculiarities. Technology that facilitates crime, and could be used to prevent crime, occurs only among ordinary or "normal" people.

There is a sense of resignation in his work on spiritualism which appears after $1900 .^{88}$ His writings from this period were no longer focussed on the triumph of science and progress, but rather on the need to recover what has been lost. At some point, Lombroso ceased to be a criminologist determined to reveal the causes of criminality in the remote past. This later Lombroso was no longer interested in studying the criminal body, nor even defending his earlier "discoveries". Deep time no longer provided the inspiration for his work. Rather, at this point, he became a historian. He latterly believed that primitive peoples possessed a wisdom superior to the advanced science of Europeans. The purpose of his life's work, and the purpose for the school of thought he has started, he contended, would be to study history as the conscious, lived experience of all people.

\section{BIBLIOGRAPHY}

Adler, J.S., On the border of Snakeland: Evolutionary Psychology and Plebeian Violence in Industrial Chicago, 1875-1920, Journal of Social History, 2003, 36, p. 541-560.

Bell, D.F., Technologies of Speed, Technologies of Crime, Yale French Studies, 2005, 108, p. 8-19.

Blom, P., The Vertigo Years: Change and Culture in the West, 1900-1914, London, Weidenfeld and Nicolson, 2008.

Calafato, T., Gli Anarchici and Lombroso's Theory of Political Crime, in Knepper, P., Ystehede, P.Y. (Eds.), The Cesare Lombroso Handbook, London, Routledge, 2013, p. 47-71.

Calafato, T., The Similarities between Lombroso's Theories on Political Crime and Contemporary Terrorism Issues, Behavioral Sciences of Terrorism and Political Aggression, 2016, 10.

Caplan, J. "One of the Strangest Relics of a Former States": Tattoos and the Discourses of Criminality in Europe, 1880-1920, in Becker, P., Wetzell, R. (Eds.), Criminals and Their Scientists: The History of Criminology in International Perspective, Cambridge, Cambridge University Press, 2006, p. 337-362.

Chambers, R., Vestiges of the Natural History of Creation, London, John Churchill, 1844.

Clarke, R., Technology, criminology and crime science, European Journal on Criminal Policy and Research, 2004, 10, p. 55-63.

Cleland, C., Historical science, experimental science, and the scientific method, Geology, 2001, 29, p. $987-990$.

Cleland, C., Methodological and epistemic differences between historical science and experimental science, Philosophy of Science, 2002, 69, p. 474-496.

Cleland, C., Prediction and explanation in historical natural science, British Journal of the Philosophy of Science, 2011, 62, p. 551-582. 
Dal Lago, E., Italian National Unification and the Mezzogiorno: Colonialism in One Country?, in Healy, R., Dal Lago, E. (Eds.), The Shadow of Colonialism on Europe's Modern Past, London, Palgrave Macmillan, 2011, p. 57-72.

Darwin, C., The Origin of Species, London, John Murray, 1859.

Davie, N., Tracing the Criminal: The Rise of Scientific Criminology in Britain, 1860-1918, Oxford, Bardwell Press, 2005.

DeLisi, M., Revisiting Lombroso, in Cullen, F.T., Wilcox, P. (Eds.), The Oxford Handbook of Criminological Theory, New York, Oxford University Press, 2013.

Elias, N., The Civilizing Process: The History of Manners, New York, Urizen Books, 1978.

Ellis, L., Walsh, A., Gene-based evolutionary theories in criminology, Criminology, 1997, 35, p. 234-337.

Ferracuti, F., Cesare Lombroso (1835-1907), Journal of Forensic Psychiatry, 1996, 7, p. 130-149.

Forgacs, D., Building the Body of the Nation: Lombroso's L'antisemtismo and fin de siècle Italty, Jewish Culture and History, 2003, 6, p. 96-110.

Garland, D., Of Crime and Criminals: The Development of Criminology in Britain, in Maguire, M., Morgan, R., Reiner, R. (Eds.), The Oxford Handbook of Criminology, Oxford, Oxford University Press, 2002, p. 7-50.

Gatti, U., Verde, A., Cesare Lombroso: Methodological ambiguities and brilliant intuitions, International Journal of Law and Psychiatry, 2012, 35, p. 19-26.

Gibson, M., Born to Crime: Cesare Lombroso and the Origins of Biological Criminology, Westport, CT, Greenwood Press, 2002.

Gibson, M., Cesare Lombroso and Italian criminology: Theory and Politics, in Becker, P., Wetzell, R. (Eds.), Criminals and their Scientists: The History of Criminology in International Perspective, Cambridge, Cambridge University Press, 2006, p. 137-158.

Gibson, M., Rafter, N., Editors Introduction, in Gibson, M., Rafter, N. (Eds.), Cesare Lombroso, Criminal Man, Durham, NC, Duke University Press, 2007, p. 1-36.

Goring, C., The English Convict, London, HMSO, 1919.

Gould, S.J., The Mismeasure of Man, New York, W.W. Norton, 1981.

Griffiths, A., Report to the Secretary of State for the Home Department on the Proceedings of the Fourth Congress of Criminal Anthropology, London, HMSO, 1896.

Holmes, O., The Common Law, Boston, Little, Brown, 1881.

Horn, D., The Criminal Body: Lombroso and the Anatomy of Deviance, London, Routledge, 2003.

Kaluszynski, M., The international congresses of criminal anthropology: Shaping the French and international criminological movement 1886-1914, in Becker, P., Wetzell, R. (Eds.), Criminals and their Scientists: The History of Criminology in International Perspective, Cambridge, Cambridge University Press, 2006.

Kenney, C., The Death of Lombroso, Journal of the Society of Comparative Legislation, 1910, 2, p. 220-228.

Killias, M., The Opening and Closing of Breaches: A Theory on Crime Waves, Law Creation and Crime Prevention, European Journal of Criminology, 2006, 3, p. 11-31. 
Knepper, P., Lombroso's Jewish identity and its implications for criminology, Australian and New Zealand Journal of Criminology, 2011, 44, p. 355-369.

Knepper, P., Lombroso and Jewish Social Science, in Knepper, P., Ystehede, P.J. (Eds.), The Cesare Lombroso Handbook, London, Routledge, 2013, p. 171-186.

Knepper, P., Laughing at Lombroso: Positivism and Criminal Anthropology in Historical Perspective, in Triplett, R. (Ed.), Wiley Handbook of the History and Philosophy of Criminology, Hoboken, NJ, John Wiley, 2018, p. 51-66.

Kurella, H., Cesare Lombroso: A Modern Man of Science, New York, Rebman Co, 1911.

Lindesmith, A., Levin, Y., The Lombrosian myth in Criminology, American Journal of Criminology, 1937, 42, p. 653-671.

Lawrence, P., History, Criminology and the "Use" of the Past, Theoretical Criminology, 2012, 16, p. 313-328.

Lombroso, C., The physiognomy of anarchists, Monist, 1890, 1, p. 336-343.

Lombroso, C., Criminal anthropology: Its origin and application, Forum, 1895, 20, p. 33-49.

Lombroso, C., The Heredity of Acquired Characteristics, Forum, 1897a, 24, p. 200-208.

Lombroso, C., Why Homicide has Increased in the United States Part I, North American Review, $1897 \mathrm{~b}, 165$, p. 641-648.

Lombroso, C., Concerning the anti-Semitic movement, To-moraux, 1897c, 3, p. 1-11.

Lombroso, C., Why Homicide has Increased in the United States. Part II, North American Review, 1898a, 166, p. 1-11.

Lombroso, C. Regressive Phenomena in Evolution, Monist, 1898b, 8, p. 377-383.

Lombroso, C., A study of Luigi Lucheni, Popular Science Monthly, 1899, 55, p. 199-207.

Lombroso, C., Musée de psychiatrie et d'Anthropologie criminelle dans l'université de Turin, Turin, Bocca Frères éditeurs, 1906a.

Lombroso, C., The Haunted Houses I Have Known, Medico-Legal Journal, 1906b, 24, p. 219-230.

Lombroso, C., My museum of criminal anthropology, New York Times, 17 February, 10, 1907.

Lombroso, C., After Death - What? Spiritualistic Phenomena and Their Interpretation, Boston, Small, Maynard and Co., 1909.

Lombroso, C., The criminal, Putnam's Magazine 1910a, 7, p. 793-796.

Lombroso, C., The bicycle and crime, Pall Mall Magazine 1910b, 20, p. 310-316.

Lombroso, C., Crime and insanity in the twenty-first century, Journal of Criminal Law, Criminology and Police Science, 1912, 3, p. 57-61.

Lombroso, C., Criminal Man, Durham, NC, Duke University Press, 2007 [Mary Gibson and Nicole H. Rafter, translations].

Lombroso, C., Ferrero, G., Criminal Woman, the Prostitute and the Normal Woman, Durham, NC, Duke University Press, 2004 [Mary Gibson and Nicole H. Rafter, translations].

Mannheim, H., Lombroso and his place in modern Criminology, Sociological Review, 1936, 28, p. 31-49. 
Mazzarello, P., Cesare Lombroso: An Anthropologist Between Evolution and Degeneration, Functional Neurology, 2011, 26, p. 97-101.

McPhee, J. Basin and Range. New York: Farrar, Strauss and Giroux, 1981.

Mennell, S., An Exceptional Civilizing Process?, Journal of Classical Sociology, 2009, 9, p. 97-115.

Monaco, F., Mula, M., Cesare Lombroso and Epilepsy 100 Years Later: An Unabridged Report of his Original Transactions, Epilepsia, 2011, 52, p. 679-688.

Natale, S., A short history of superimposition: From spirit photography to early cinema, Early Popular Visual Culture, 2012, 10, p. 125-145.

Nye, R., Heredity or milieu? The foundations of modern European criminological theory, Isis 1976, 67, p. 334-355.

Pancaldi, G. Darwin in Italy: Science Across Cultural Frontiers. Bloomington: Indiana University Press, 1991.

Persell, S., Jean de Lanessan and the French positivist school of criminal reform, 1880-1914, Criminal Justice Review, 1987, 12, p. 1-6.

Pinker, S., The Better Angels of Our Nature: The Decline of Violence in History and its Causes, London, Allen Lane, 2011.

Pisciotta, A., Scientific Reforms: “The New Penology" at Elmira, 1886-1900, Crime and Delinquency, 1983, 29, p. 613-630.

Pike, L., A History of Crime in England, vol 2., London, Smith, Elder, 1876.

Pry, M., "Everybody Talks Wheels": The 1890s Bicycle Craze in Phoenix, Journal of Arizona History, 1990, 31, p. 1-18.

Rafter, N., Creating Born Criminals: Biological Theories of Crime and Eugenics, Urbana, IL, University of Illinois Press, 1997.

Rafter, N., Cesare Lombroso and the Origins of Criminology: Rethinking the Criminological Tradition, in Henry S., Lanier, M. (Eds.), The Essential Criminology Reader, Boulder, CO, Westview, 2006, p. 33-42.

Rafter, N., Criminology's darkest hour: Biocriminology in Nazi Germany, Australian and New Zealand Journal of Criminology, 2008a, 41, p. 387-306.

Rafter, N., The Criminal Brain: Understanding Biological Theories of Crime, New York, New York University Press, 2008b.

Rafter, N., Ystehede, P., Here be dragons: Lombroso, the gothic, and social control, in Deflem, M. (Ed.), Popular Culture, Crime and Social Control, Bingley, UK, Emerald, 2010, p. 263-284.

Regener, S. "Criminological museums and the visualization of evil" Crime, History and Societies 2003, 7, p. 2-13.

Reiger, B., Modern Wonders: Technological Innovation and Public Ambivalence in Britain and Germany, 1890s to 1933, History Workshop Journal, 2003, 55, p. 153-176.

Rock, P., Cesare Lombroso as a signal criminologist, Criminology \& Criminal Justice, 2007, 7, p. 117-133.

Rooney, D., Nye, J., Greenwich Observatory time for the public benefit: Standard time and Victorian networks of social regulation, British Journal for the History of Science, 2009, 42, p. 5-30.

Rubenstein, D., Cycling in the 1890s', Victorian Studies, 1977, 21, p. 47-71. 
Schuerman, W., Liberal democracy and the empire of speed, Polity, 2001, 34, p. 41-67.

Shichor, D., The French-Italian Controversy: A Neglected Historical Topic in Criminological Literary, Journal of Criminal Justice Education, 2010, 21, p. 211-218.

Simon, J., Positively Punitive: How the Inventor of Scientific Criminology Who Died at the Beginning of the Twentieth Century Continues to Haunt American Crime Control at the Beginning of the Twenty-First Century, Texas Law Review, 2006, 84, p. 2135-2172.

Simpson, J., Campbell, L., Methods of Evolutionary Sciences, in Buss, D. (Ed.), The Handbook of Evolutionary Psychology, Hoboken, NJ, Wiley, 2005, p. 119-144.

Smart, C., Women, Crime and Criminology, London, Routledge and Kegan Paul, 1977.

Speranza, G., Lombroso in science and fiction, Green Bag, 1901, 3, p. 475-477.

Spierenburg, P, Violence and the Civilizing Process: Does it Work?, Crime, History \& Societies, 2001, 5, p. 87-105.

Starr, D., The Killer of Little Shepherds: The Case of the French Ripper and the Birth of Forensic Science, London, Simon \& Schuster, 2011.

Weiner, M., Evolution and history writing, Cultural and Social History, 4, 2007, p. 545-551.

Wetzell, R., Inventing the Criminal: A History of German Criminology, 1880-1945, Chapel Hill, NC, University of North Carolina Press, 2008.

Wetzell, R., Psychiatry and criminal justice in modern Germany, 1880-1933, Journal of European Studies, 2009, 39, p. 270-289.

Whibley, C., Science, real and false - Lombroso's method', Blackwood's Magazine, 1909, 186, p. 843-850.

Wilson, T., Criminal Anthropology, Annual Report of the Board of Regents of the Smithsonian Institution, Washington, DC, Government Printing Office, 1891, p. 617-686.

Wolfgang, M., Cesare, 1835-1909, in Mannheim, H., Pioneers in CriminologyPioneers in Criminology, Montclair, NJL Patterson Smith, 1972, p. 232-291.

Wright, J.P., Cullen, F.T., The Future of Biosocial Criminology: Beyond Scholars, Professional Ideology, Journal of Contemporary Criminal Justice, 2012, 28, p. 237-253.

Ystehede, P.J., In the Twilight of Good and Evil: Cesare Lombroso and the Criminological Imagination, Saabrücken, VDM Verlag, 2008.

Ystehede, P.J., Demonizing Being: Lombroso and the Ghosts of Criminology, in Knepper, P., Ystehede, P.J. (Eds.), The Cesare Lombroso Handbook, London, Routledge, 2013, p. 72-97.

Zimmern, H., Professor Lombroso's new theory of political crime', Blackwood's Magazine, 1897, 149, p. 202-211.

Zimmern, H., Criminal anthropology in Italy. Part II, The Green Bag, 1898, 10, p. 3.

\section{NOTES}

1. Rafter (2006); Gibson (2006); Gatti and Verde (2012); Knepper (2018).

2. Rock (2007). For examples on distancing, see Goring (1919); Lindesmith and Levin (1937); Smart (1977).

3. Ellis and Walsh (1997); Wright and Cullen (2012); De Lisi (2013). 
4. Wolfgang (1972); Gibson (2002); Ferracuti (1996); Horn (2003).

5. Lombroso (2007).

6. Gibson and Rafter (2007).

7. Garland (2002).

8. Lombroso (1909).

9. Lombroso (1906a).

10. Kaluzynski (2006); Shichor (2010).

11. Montaldo (2013).

12. Lombroso (1910a).

13. Lombroso (1907).

14. Regener (2003).

15. Kurella (1911, p. 133-134) notes the influence of Lyell on Lombroso's outlook. In Principles of Geology (1830), Lyell argued that the earth had not been created by a single cataclysmic event, but formed over vast periods of time through geological processes that continued into the present. Geologist John McPhee coined the term "deep time" in 1981 to express the formation of earth over billions of years.

16. Mazzarello (2011).

17. Pancaldi (1991).

18. Chambers (1844, p. 355-356). Davie (2005) refers to early attempts to develop a science of criminology in Britain as "tracing the criminal" and this is a good description.

19. Lombroso (1910a).

20. Dal Lago (2011).

21. Persell (1987).

22. Lombroso (1897a). Lombroso contributed to work on "Jewish race science". See Knepper (2011, 2013).

23. Mannheim (1936); Wolfgang (1972); Gould (1981).

24. Cleland (2001, 2002, 2011).

25. Cleland (2002, 2011).

26. Lombroso (1910a).

27. Cleland (2002, p. 492).

28. Cleland (2011, p. 574-575).

29. See, for example, Caplan (2006).

30. Starr (2011, p. 18, 127).

31. Cleland (2002).

32. Cleland (2002, p. 482).

33. Lombroso and Ferrero (2004, p. 289); Rafter (1997, p. 179-180).

34. His colleague, Alfredo Niceforo made this argument directly in L'Italia barbara contemporanea (1898), "Barbaric Contemporary Italy": the peoples of Sardinia, Sicily and the Mezzogiorno are "still primitive, not completely evolved, less civilized and refined than the people of the North", Dal Lago (2011, p. 61).

35. Lombroso (2007, p. 222).

36. Lombroso (2007).

37. Simon (2006, p. 2153).

38. Elias (1978).

39. Pinker (2011).

40. Calafato (2016) compares recent views of academic experts in terrorism with Lombroso's statements about anarchists and finds a great deal of similarity.

41. Lombroso (1897c). Mennell (2009) starts with virtually same question and offers the "civilizing process" explanation - without mentioning Lombroso. He suggests that relative 
weakness of state institutions in the southern United States explain higher rates of violence among African-Americans.

42. Pisciotta (1983).

43. Lombroso (1898a).

44. Lombroso (1898b).

45. Lombroso (1898b).

46. Spierenburg (2001, p. 102).

47. Adler (2003, p. 553) and Weiner (2007, p. 547) propose that while evolutionary psychology can account for what masses of people have been doing over the long-term, it is less useful for specific populations in the short-term.

48. Lombroso (2007, p. 299).

49. Forgacs (2003); Knepper (2011).

50. This belief in the irreversibility of scientific progress remains. As two recent proponents of evolutionary psychology put it, Darwin had "an idea that would forever change biology and the life sciences [...]", Simpson and Campbell (2005, p. 119).

51. Lombroso (2007, p. 162).

52. Lombroso (1895).

53. Nye (1976); Shichor (2010).

54. Zimmern (1898, p. 384).

55. Lombroso (2007, p. 92). The most important principle of social defence, Lombroso said, was preventive isolation. Teachers in schools would use principles of social defence to recognize the signs of incorrigibility in children and distinguish innate criminality from temporary criminality of youth. The new principles of social defence, such as taxing alcohol, instituting probation, establishing asylums for insane criminals and prisons for incorrigibles would do away with the "absurdities" of the legal system based on a theory, such as juries and pardons Lombroso (2007, p. 335-336).

56. Lombroso (1912).

57. Lombroso (1912).

58. Lombroso (1897c).

59. Lombroso's son-in-law, Mario Carrara, became one of only thirteen academics who refused to swear allegiance to Mussolini's fascist government in 1929, Monaco and Mula (2011, p. 686).

60. Rafter (2008a, 2008b); Wetzell (2008, 2009).

61. Gibson (2002, p. 141).

62. Lombroso (2007, p. 348).

63. Wilson (1891, p. 625).

64. Griffiths (1896, p. 11).

65. Speranza (1901, p. 477).

66. Whibley (1909, p. 843-844). From the start, Lombroso attracted critics. Kenney (1910) says that as a prison physician, his practice of carefully documenting the physical peculiarities of his patients was a novelty in Italy at the time. His contemporaries mocked his approach by referring to him as l'alienista della stadera, the "scales-and-weights surgeon".

67. Ystehede (2008).

68. Calafato $(2013,2016)$.

69. Lombroso (1895).

70. Lombroso (1890).

71. "The idea of conquering anarchy by killing anarchists is not valid", Lombroso declared. Because so many anarchists represented cases of mental instability, aggravated by personal and family histories of poverty, alcoholism, and misfortune, the execution of one place would only be filled by another. Breaking up the large estates and improving conditions in agriculture was the policy that needed to be undertaken. If the government did not do this, the political disease of 
anarchism would engulf them. Execution of anarchists was an "imbecile idea" comparable to "putting down the doctors who propose remedies", Lombroso (1899).

72. Zimmern (1897, p. 203).

73. Blom (2008); Bel (2005); Reiger (2003). David Harvey, a geographer, coined the phrase "timespace compression" in 1989 to refer to the experience of postmodernity, in which the increased speed of institutions has the effect of shrinking or compressing distance. See Scheuerman (2001). 74. Lombroso (2007, p. 121).

75. Lombroso (2007, p. 135-136). In current parlance, Lombroso might be considered an advocate of situational crime prevention and crime science, Clarke (2004).

76. Rubenstein (1977); Pry (1990). Killias (2006) pursues a similar conception of the relationship between technology, time and crime with his theory of "breaches" and "crime waves".

77. Lombroso (1900b).

78. Rooney and Nye (2009).

79. Josef Conrad refers to Lombroso in his novel The Secret Agent (1894) about an anarchist plot to bomb the Greenwich Observatory. In the story, Vladimir instructs Verloc to carry out an outrage, directed not at royalty or politics, but science. As he explains, the attack must be against the most revered institution and the most widely-known "The whole civilised world has heard of Greenwich".

80. Ystehede (2013).

81. Natale (2012).

82. Ferraculti (1996, p. 134).

83. Lombroso (1906b).

84. Lombroso (1909).

85. Lombroso (1909, p. 346).

86. Lombroso (1909, p. 204).

87. Lombroso (1909).

88. Before his death, Lombroso may have turned, or returned, to Judaism. There is an obituary written by his son-in-law, Guglielmo Ferraro, a man who knew Lombroso well, that refers to Lombroso as a "Jewish prophet". It is strange thing to write about a man who championed a secular, scientific view throughout his life, unless Lombroso told him how he wanted to be remembered. See Knepper (2011).

\section{ABSTRACTS}

This article outlines and interrogates six different conceptions of time embedded in Lombroso's writings, arguing that research to date has underappreciated both the range and significance of the different concepts of time he deployed. The article outlines the six conceptions of time (deep time, time moving at multiple speeds, time as progress, fitful time, time speeding up and time moving backwards) and demonstrates the importance of each on his body of work and the development of his ideas. Throughout, the article argues that recognising the different concepts of time deployed by Lombroso also gives a fresh appreciation of the extent to which he both drew on and was embedded in broader currents of contemporary thought.

Cet article met au jour et interroge six conceptions différentes du temps contenues dans les écrits de Lombroso, affirmant que la recherche à ce jour a sous-estimé à la fois la portée et la 
signification des différents concepts du temps qu'il a déployés. L'article décrit ces six conceptions du temps (le temps profond, le temps qui passe à des vitesses différentes, le temps comme progrès, le temps sporadique, le temps qui s'accélère et le temps qui revient en arrière). Il démontre l'importance de ces six notions dans l'œuvre et les idées de Lombroso. Ce faisant, l'auteur soutient que la reconnaissance des différentes conceptions du temps mobilisées par Lombroso donne également une nouvelle appréciation de l'étendue de son inscription dans les courants de pensée de l'époque.

\section{AUTHOR}

\section{PAUL KNEPPER}

Department of Law \& Justice Central Washington University Paul.Knepper[at]cwu.edu 